Dublin, Ireland

\title{
Special Education Student Teachers' Opinions about Online Supervision amidst Covid-19
}

\author{
Uzeyir Emre Kiyak ${ }^{1, *}$ and Gulcihan Yazcayir ${ }^{2}$,

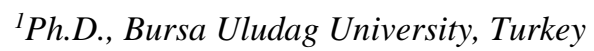 \\ ${ }^{2}$ Assist. Prof. Dr., Bursa Uludag University, Turkey
}

\begin{abstract}
.
One of the main issues in the educational systems is the quality of the teachers. The quality of the teachers is directly linked to teacher training programs which consist of theory and practice. Teaching practice is of great importance especially in special education departments. However, the COVID-19 pandemic has resulted in schools and universities shut all across the world and has interrupted traditional teaching practice in education departments. Therefore, education provided to students with special needs and supervision delivered to student teachers in teaching practice changed dramatically. The main aim of this current study is to investigate the student teachers' opinions in a special education department in Turkey about supervision provided to them in teaching practice amidst COVID-19. Thirteen student teachers were interviewed in 2020-2021 academic year and the data obtained from semi-structured interviews were analyzed using inductive analysis. Findings of the study demonstrated that online supervision had some facilities as flexibility in time and space; however, had created some difficulties especially in internet access and teaching experience with students. In addition, the participants suggested guidance for technology-based instructional tools for improve their practices.
\end{abstract}

Keywords: supervision, COVID-19, special education, student teachers, teacher practice program.

\section{Introduction}

Contemporary definition of teaching supervision is a process of guiding some developmental features in student teachers in order to promote their professional growth such as knowledge, teaching skills, decision making strategies, problem solving abilities and reviewing their own implementation by sticking into the supervision principles offered by school teachers and university tutors (Kalule \& Bouchamma, 2014; Sergiovanni \& Staratt, 2007).Claiming themselves as the most important element in supervision process (Conderman et al., 2005; Connelly \& Graham, 2009), university tutors are supposed to be experienced in teaching (Murray \& Male, 2005) and also competent in "educational sciences", "communication" and "particulars in research" (Boyd et al.,2007; Bullough, 2005; Guilfoyle et al., 1997; Harrison \& McKeon, 2008). The implementations and skills which might contribute to development of 
Dublin, Ireland

student teachers can be arrayed as following; (a) taking effective practices as models, (b) guiding student teachers on further planning, (c) providing constructive feedback to student teachers to promote their implementations inclusively in an ongoing supervision process, (d) sharing sources (Butler \& Cuenca, 2012; Giebelhaus \&. Bowman, 2002; Sayeski \& Paulsen, 2012). The ultimate aim of supervision is to assist student teachers to become proficient teachers who are able to employ teaching methods effectively, manage classrooms, develop their capacities and build strong communication networks with students (Cameron et al., 2007; Smith \& Lev-Ari, 2005).

As Klinger et al., (2003) put forward, providing supervision is the key component in teacher education as student teachers could have the opportunity to receive consultancy regarding their early implementations in real classrooms, which also helps them to combine their theoretical and field knowledge in order to evaluate their performance of teaching. Qualified supervision process that consists of effective consultancy is extremely important for the development of qualified and self-conscious teachers (Leko et al., 2012; National Council for Accreditation of Teacher Education [NCATE], 2010), and improves their instructional qualifications (Cameron et al., 2007; Smith \& Lev-Ari, 2005).

When it comes to special education, the supervision process is of great importance because of the fact that special education teachers and student teachers need to consider many variables including behavior and classroom management; individual differences and performances of students (Connelly \& Graham, 2009). Keeping these noted, it is indicated that newly graduated special education teachers have difficulties in behavior management with different pupil specialties, developing and implementing IEP and communication and collaboration with families (Conderman \& Stephens, 2000; Whitaker, 2000). Within this frame, findings of researches in which opinions of student teachers were examined are listed as following: (a) their theoretical knowledge needs improvement (Morewood, 2012), (b) they have difficulties in classroom and behavior management, providing motivation of pupils and adaptation of instruction (Ergul et al., 2013; Giles \& Kent, 2016), (c) they are concerned about different disabilities and level of which are novel to them (Giles \& Kent, 2016), (d) they have difficulties in transferring theoretical knowledge into implementation (Ergul et al., 2013). Apart from these, student teachers need supports in terms of communication and collaboration with families and student teachers suggest that (a) the period of supervision should be enlarged (Dedeoglu et al., 2004; Ergenekon et al., 2008; Ergul et al., 2013), (b) Theoretical courses should be instructed parallel with implementation (Dedeoglu, et. al.,2004; Ergul et al., 2013), (c) supervisors should be responsible for fewer student teachers (Ergenekon et al., 2008), (d) supervisors should carry out their responsibilities (setting an example of instruction, providing written feedback, etc.) as indicated in literature (Ergenekon et al., 2008).

Covid-19, affected all areas, of course including education systems and universities and carried education clinical settings to virtual settings. Covid-19 and lockdown as a result of it caused changes in interacting, teaching and learning ways of student teachers and supervisors and their roles in supervision process (Flores \& Gago 2020) and created huge difficulties in putting theory into practice (Hazir \& Kiyak, 2021). It is stated that there were not any universally agreed online teacher training program for student teachers and supervisor until Covid-19 blowout (Feher \& Graziano, 2016; Flores \& Gago, 2020; Rice \& Deschaine, 2020). Thus, this extremely new context for everyone has reshaped the traditional supervision provided to student teachers 
Dublin, Ireland

direction to a virtual setting with the adaptations from the real setting and has changed the interaction of student teachers, supervisor, cooperating teachers, pupils and their parents (Flores \& Gago, 2020).

As a result of Covid-19 pandemic, the universities in Turkey was shut in 2020-2021 academic year. Therefore, all the courses including teaching practice linked with supervision had to be provided in online platform. Strikingly, Bullock et al. (2008), indicate that special education teachers having graduated from traditional special education departments have more reliability and qualification in class implementation compared with the ones having graduated from distance-education and they suggest to searching for ways to improve distance-education in preparing special education teachers. A recent study conducted in a special education department of a university in Turkey showed that student teachers were aware of the process of supervision and their roles within it (Hazir \& Kiyak, 2021). They suggest that the opinions of student teachers and newly graduated special education teachers should be taken into consideration in special education departments in order to make the whole teaching practice process more beneficial for everyone involved in it. Considering all these, there is a need for conducting research to improve online supervision to grow better special education teachers. Hence, the main aim of this current study is to investigate the online supervision in one special education department's teaching practice amidst Covid-19 from the student teachers' perspective to contribute to the supervision literature and university tutors in special education departments. Thus, the following research questions were addressed:

1. How do student teachers perceive the online supervision within a special education department's teaching program amidst Covid-19?

2. What is their recommendation to provide better online supervision to future special education student teachers?

\section{Method}

\subsection{Research design}

Aiming to examine in depth online supervision experiences of student teachers with teaching practice lessons in special education department amidst Covid-19 pandemic, in this paper phenomenological design from qualitative research methods has been employed (Creswell, 2007; Mertens, 2010).

\subsection{Data collection technique}

By means of semi-structured interviews has the date of this research been collected (Creswell, 2007; Given, 2008). Over the course of global outbreak, as a result of which students have been obliged to stay in their home cities and attend classes virtually, the interviews have been conducted via Google MEET online (Stewart \& Williams, 2005). The process of interviews were recorded and the mean time of them is 9 minutes with a total of 129 minutes.

\subsection{Participants}

The participants of the research have been designated with criterion sampling methods from purposive sampling methods in order for them to contribute according to the identified phenomenon (Mertens, 2010; Miles \& Huberman, 1994). Both being academicians from a 


\section{3rd International Conference on Modern Research in EDUCATION, TEACHING AND LEARNING}

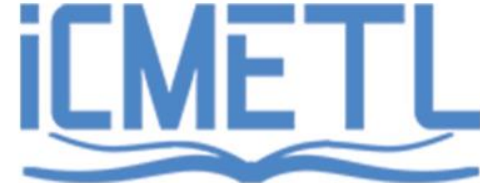

20 - 22 August 2021

Dublin, Ireland

special education department, the researchers have set the participant criteria as being a special education candidate delivering their practicum. To this respect, the participants of the research comprise of special education student teachers who were offered supervision during the academic term 2020-2021in Turkey. In addition to these, via WhatsApp, the participants have been informed about the purpose of the study during their selection process and their view on voluntary participation to the research has been asked. In this regard, the participants of this research are 13 student teachers from the department of special education.

Characteristics regarding the participants are as follows;

- Participant 6 and Participant 12 also completed their undergraduate education from a different department.

- Special education is the other participants' first undergraduate program.

\subsection{Data analysis}

Data analysis of the research have been carried through inductive method. Data collected online meetings via MEET have been taken under record with short notes and tape recording. After transcribing the voice records, the researchers have put the participants into codes independently of each other. On the basis of the codes at hand, after negotiation process, themes and sub-themes have been reached (Creswell, 2007; Given, 2008; Miles \& Huberman, 1994).

\subsection{Validity, reliability and morality}

Numerous measurements in terms of validity and reliability have been taken in the research paper. On that note, offered by Miles \& Huberman (1994), percentage of consistency formula 'reliability $=$ number of agreements $/$ (number of agreements + number of disagreements) for reliability calculation. According to Miles \& Huberman (1994), $90 \%$ and above consistency between coders is desirable for reliability. Reliability for this current research conducted on the agreed codes was found 100\%. Furthermore, researchers provided detailed descriptions by providing direct quotation from participants' opinions (Creswell, 2007; Miles \& Huberman, 1994). Researchers obtained permissions from participants in online platform by a digital form. Besides, having been stated on the form, it was orally stated that the participants have the freedom to leave the research whenever they feel so. The researchers also used nicknames such as Participant-1, Participant-2 for the participants to ensure their privacy as well as protecting their personal information.

\section{Findings}

The researchers in this study reached two main themes as a result of the data obtained from special education student teachers by semi-structured interviews about supervision provided to them throughout their teaching practicum amidst Covid-19. The themes were "perceptions about online supervision" and "suggestions for improving online supervision", subthemes associated with the main themes are explained under the titles following;

\subsection{Perceptions about online supervision}

Two sub-themes were emerged as a result of analysis under the perceptions about online supervision theme as follows: (a) "facilities provided by online supervision and (b) difficulties encountered amidst online supervision (see Figure 1.) 
Dublin, Ireland

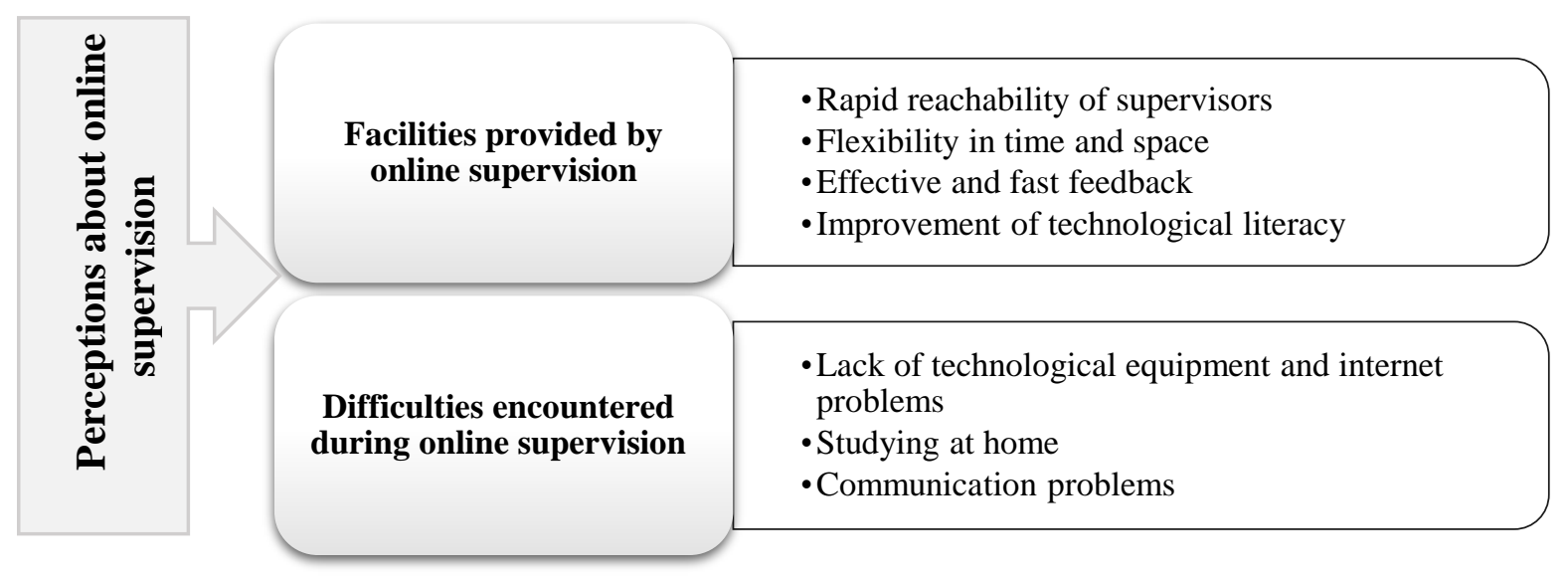

Figure 1. Facilities provided by online supervision

Participants reported the fact that there were many facilities provided by their online supervisions. These were arrayed as "rapid reachability of supervisors", "flexibility in time and space", "effective and fast feedback" and "improvement of technological literacy".

All of the participants reported that the most important facility provided by online supervision rapid reachability via internet-based communication networks; "While face-to-face supervision was supposed to be more reachable, this (online supervision) was more accessible. Whenever we need, we could communicate easily with our supervisors via WhatsApp, Zoom, Meet or email." (Participant-5).

Similar to rapid reachability, all participants highlighted that online supervision served facility in effective and immediate feedback. Participant- 2 reported that "We could receive regular and direct feedback about our lesson plans or related with the activities we prepared and our instructions or communications we set with students.". "Receiving feedbacks by constantly meeting was very beneficial for our lesson plans and instructions."

Furthermore, seven participants reported that online supervision provided flexibility in time and space. Participant-5 said "Whenever and wherever we wanted, we could connect to the meetings and we could get in touch easily." In addition, two participants expressed that online supervision helped them improve their technological literacy, "My knowledge about technological devices was very weak, I had to improve my knowledge for this online process" (Participant-8).

\subsubsection{Difficulties encountered during online supervision}

The other sub-theme occurred under the main theme of "Perceptions about Online Supervision" was "difficulties encountered during online supervision". According to the analysis, the findings about "lack of technological equipment and internet problems", "studying at home" and "communication" problems were emerged and examined under the difficulties encountered during online supervision. 
Dublin, Ireland

Most of the participants highlighted that they had difficulties regarding with connection and lack of technological devices needed for online supervision process; "There was technological problems and internet disconnection. Not everyone did have a personal computer or a tablet. Some (of the student teachers) do not have internet connection or even opportunity for this." (Participant-4). Additionally, five participants expressed that studying at home was a challenge for them as they lack of privacy, was harder than it should be. It is evident that studying/working from home had negative impact on online supervision in terms of both deciding on the time when everyone is available to set their environment for learning and psychological state of student teachers as well; "As we were all at home, it was hard to find a common period of time appropriate for each one of us. Not everyone in a group does share the same home settings, state of families, socioeconomic states, psychological state... I personally think psychological state as the most important of them all. It is commonly thought that duties should not be hindered as long as there is not a physical obstacle but psychological state is as important as physical obstacles." (Participant-5). Another difficulty encountered in online supervision process, expressed by three student teachers, was communication problems, "Being understood correctly, that is to say, there were times that we could not achieve compatibility. In other words, there were times that we had to find a common channel." (Participant-3).

\subsection{Suggestions for improving online supervision}

In this study, researchers reached the theme named "suggestions for improving online supervision" as a result of the data analysis obtained from interviews conducted with special education student teachers. The main theme was merged into three sub-themes (See Figure 2.) Findings obtained under this theme are explained in following sections.

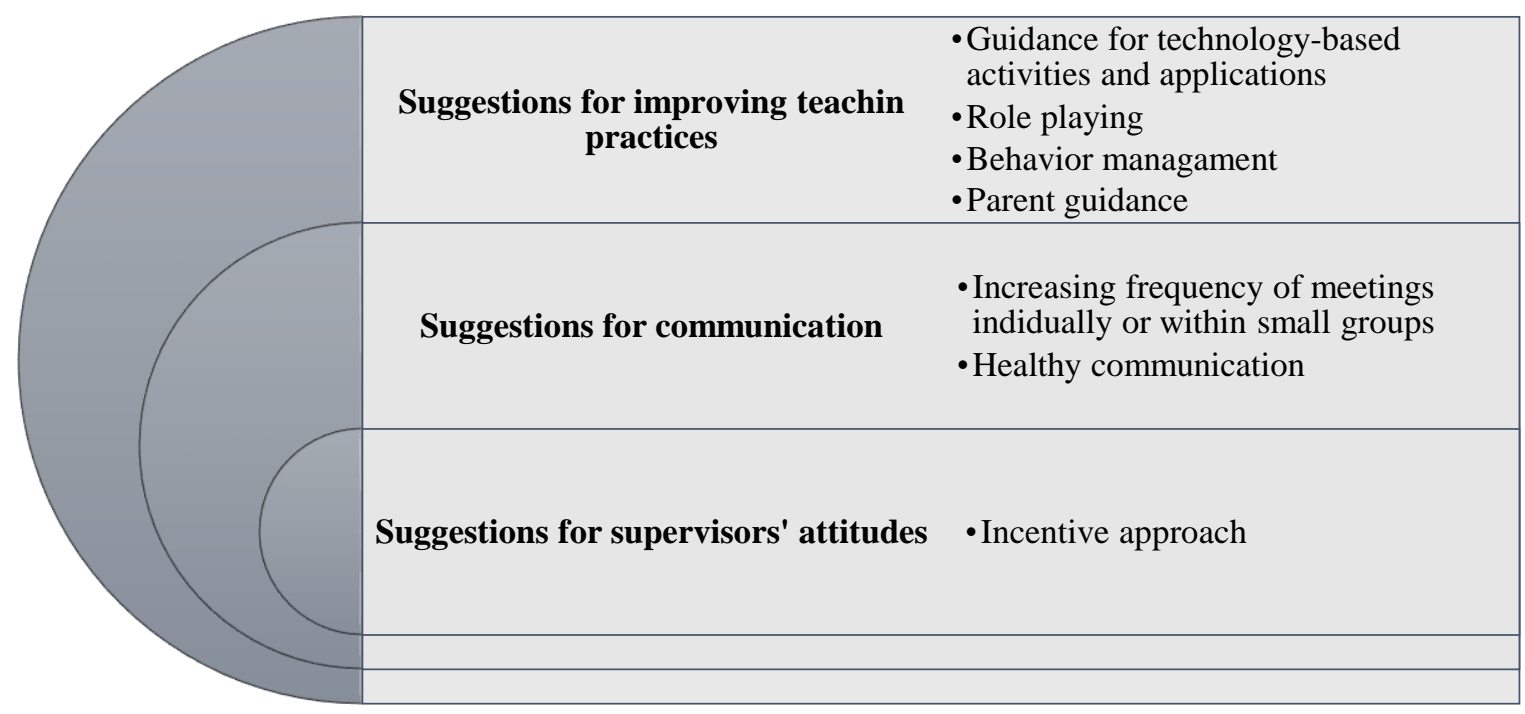

Figure 2. Suggestions for improving online supervision 


\section{3rd International Conference on Modern Research in EDUCATION, TEACHING AND LEARNING}

\subsubsection{Suggestions for improving teaching practices}

Comprehensive findings emerged under "Suggestions for improving teaching practices" subtheme linked to the suggestions for improving online supervision in the study. According to the sub-theme, five participants presented suggestions to be provided guidance for planning technology-based activities and familiarization to technology-based applications related to distance education and online practices; "Guidance may be provided for technology-based activities. Besides, making digital education applications more effective, training about these applications, how to use them, should be provided." (Participant-6).

Furthermore, six participants reported that their supervisor role-played by acting as a student and they instructed to the supervisor within the lesson plan they prepared and they received feedback by the supervisor for this role-playing opportunity. Within this context, they also suggested that practices such as role-playing and video modelling instruction samples should be involved in online supervision. For instance, Participant-12 expressed that role playing was useful by saying "Our supervisor made us prepare a lesson plan and instruct according to the plans we designed by acting as a student in an online platform. It was very beneficial, as we do not have any teaching experience with a student. These activities may be included in the supervision much more."

In other respects, two participants suggested that supervision should be delivered for behavior management in the online courses on the digital platforms, "It is hard to intervene and manage the problem behaviors in distance education. We had courses about behavior management in novel classroom settings but we need guidance on how to exhibit positive approaches in online courses by using technology." (Participant-3).

Besides, because of the consideration that parent existence in online education, three participants reported that they had difficulties in controlling the process and they needed for family support on the physical environment for the student, "The most inadequate part that I felt in the process was parent guidance and education, we were required to collaborate with parents for supporting students with special needs in the online process, parent guidance may also be included in online supervision." (Participant-8).

\subsubsection{Suggestions for communication}

Analysis of obtained data demonstrated that there were many findings about communication for improving online supervision. Within this context, seven participants expressed their opinions about frequency of meetings individually or within small groups, "Supervisors had better often meet with student teachers individually." (Participant-2). Participant-9 told that "Supervisors should meet with fewer student teachers in a certain period of time but more than one in a week, for answering questions and providing feedback." In addition to frequency of communication, three student teachers presenting their suggestions about setting a systematic and common operation by informing all the stakeholders at the beginning of the process to establish healthy communication among all the stakeholders, "Certain systematic and common operation, in other words orientation should be provided about how this process would be operated. (Co-operating) Teachers, students (teachers) should have information about the process." (Participant-7). 


\section{3rd International Conference on Modern Research in EDUCATION, TEACHING AND LEARNING}

\subsubsection{Suggestions for supervisors' attitudes}

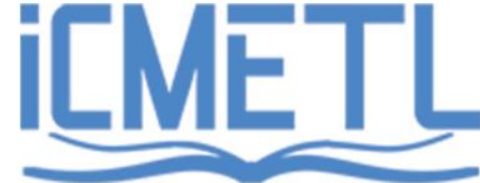

20 - 22 August 2021

Dublin, Ireland

The other findings proved for improving online supervision were categorized as suggestions for supervisors' attitudes. According to this, eight participants expressed their suggestions about supervisors' attitudes towards student teachers should be incentive by considering student teachers' personal or private conditions, "Our motivation was lowered, we felt sick, but despite all, thanks to our supervisors' supports, specialty in the field and experience, this term was productive. Supervisors' attitudes affect student teachers' motivation." (Participant-13).

\section{Conclusion and Discussion}

The researchers aimed to investigate opinions of special education student teachers about online supervision operated in 2020-2021 academic year in Turkey amidst Covid-19 pandemic by conducting semi-structured interviews in this phenomenological research and reached significant results as consequences of analysis of obtained data. Within this context, it was found that online supervision provided many facilities to special education student teachers. Accordingly, the finding that online supervision provided time and space flexibility as a result of internet communication tools and student teachers communicated rapidly to the supervisors amidst online supervision is similar to the findings of other studies proved that online supervision was operated without time and space restriction with technological tools and commutation webs (Chapman et al., 2011; Perry, 2012). In addition to this, feedbacks were rapidly provided to student teacher for their lesson plans and their instruction by supervisors during the online supervision. This finding is consistent with the findings of previous studies conducted with web 2.0 tools which provided facilities in file sharing and feedback (Duncan, 2021; Du et al., 2021). Moreover, the study demonstrates that online supervision contributes student teachers' technological literacy development. Considering these findings and the technological progress, as Chapman et al. (2011) expressed, online supervision process could be re-structured convenient to this era by including new perspectives into the process.

In addition to these facilities provided by online supervision, findings about difficulties were found in online supervision as lack of technological devices, internet connection problems, studying at home and communication problems. Lack of technological devices and internet connection problems may be solved with collaboration among foundations and persons, considering the era we live that technology progress rapidly and technology-based devices are used in every part of life. Similar to findings of previous studies (Agricola et al., 2021; Chapman et al., 2011; Perry, 2012), communicating within small groups and often may be applied for the solution of communication problems including problems in expressing themselves correctly and being understood which is one of the findings of the study.

Besides perception of student teachers about online supervision, there were many suggestions for improving online supervision that special education student teachers told in the study. Within this context, most of the special education student teachers expressed their need for supervision to designing technology-based practices and familiarization to technology-based applications. Furthermore, they suggested to improve their instruction by using role-playing and applying case-scenarios. This finding is consistent with previous studies findings that roleplaying may be an effective method to be used in teacher education (Grossman et al., 2009; Leaman \& Flanagan, 2013). Likewise, they also reported that they need consultancy about 


\section{3rd International Conference on Modern Research in EDUCATION, TEACHING AND LEARNING}

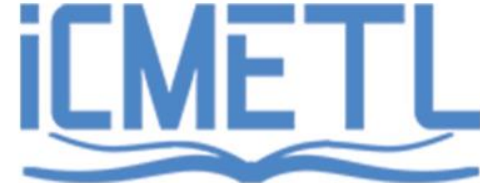

20 - 22 August 2021

Dublin, Ireland

behavior management and using effective behavioral interventions for problem behaviors of students with special needs in order to maintain effective teaching practices in digital platform. Considering ethical considerations and problem behaviors mostly requires face-to-face interaction and physical intervention, experiencing and learning behavior management in online process may be difficult for special education student teachers. Thus, virtual reality, is an emerging technology, an urgent need for online supervision for student teachers to gain experience for classroom setting, especially in behavior management.

Another suggestion for teaching practices sub-theme was supervision about parent guidance on digital platform considering the need that since parents involved in education of their children during the teaching practices conducted online amidst Covid-19 pandemic. Parents were required to have many responsibilities for their children during the process and one of the most important responsibility was teaching to their children as teachers (Yucesoy-Ozkan et al., 2020). It may not be correct that supervision about family guidance is directly because of the teaching practice conducted online, because before the Covid-19 pandemic collaboration between parents and student teachers were limited. However, the sudden change in teaching practice turned into online that was the first in the history of the Turkey were required much more collaboration between teachers and parents, so do student teachers since they implemented their lesson plans with the help of parents. Hence, the need of parent guidance become clear with the pandemic. Therefore, the results of our study, proving the existing literature, demonstrate the importance and requirement of parent education and parent involvement in special education and collaboration between parents.

Finally, many people had to work and study at homes due to lock-downs amidst Covid-19. It was highlighted in this study, likewise many studies (e.g., Ammar et al., 2020; Khan et al., 2020) that working/studying at home had difficulties. As found in the study, there are individual differences considering opportunities and private conditions during working/studying at home. The suggestions of student teachers about supervisors' incentive attitudes is the one of the significant findings of the study considering both lockdowns during the Covid-19 pandemic and personal opportunities. It has been well-known fact that negative conditions like loss of a close have negative effects of human psychology (Liu et al., 2019; Tull et al.,2020). It can be precisely foreseen negative effect of an additional negative and extraordinary condition as restriction of whole life. The study conducted amidst the pandemic and distance education because of lockdown associated with the pandemic, therefore, it has to be stressed that protecting and supporting psychological/mental wellness of student teachers should be the priority of supervisors.

Considering the results of the study which investigated the opinions of special education student teachers about the online supervision conducted for the first time in Turkey, it is recommended to re-structured online supervision to be included in future teaching practices as it facilitates the process as by providing flexibility time and space, reachability. For the restructuring, the dimensions of the online supervision are required to be determined primarily. The first evidence-based thought for determining the dimensions of online supervision is conducting comprehensive research included in more stakeholders. Additionally, applied research may be recommended to conduct to find solutions to the problems or difficulties may be encountered during the online supervisions. 


\section{References}

Agricola, B. T., Prins, F. J., van der Schaaf, M. F., \& van Tartwijk, J. (2021). Supervisor and student perspectives on undergraduate thesis supervision in higher education. Scandinavian Journal of Educational Research, 65(5), 877-897. https://doi.org/10.1080/00313831.2020.1775115

Ammar, A., Brach, M., Trabelsi, K., Chtourou, H., Boukhris, O., Masmoudi, L., ... \& ECLBCOVID19 Consortium. (2020). Effects of COVID-19 home confinement on eating behaviour and physical activity: results of the ECLB-COVID19 international online survey. Nutrients, 12(6), 1583.

Boyd, P., Harris, K., \& Murray, J. (2007). Becoming a teacher educator: Guidelines for the induction of newly appointed lecturers in initial teacher education. ESCalate Education Subject Centre.

Bullock, L. M., Gable, R. A., \& Mohr, J. D. (2008). Technology-Mediated Instruction in Distance Education and Teacher Preparation in Special Education. Teacher Education and Special Education, 31(4), 229-242. https://doi.org/10.1177/0888406408330644

Bullough Jr, R. V. (2005). Being and becoming a mentor: Teacher educators and teacher educator identity. Teaching and Teacher Education, 21(2), 143-155.

Butler, B. M., \& Cuenca, A. (2012). Conceptualizing the roles of mentor teachers during student teaching. Action in Teacher Education, 34(4), 296-308.

Cameron, M. (2007). Learning to teach: A literature review on induction theory and practice. New Zealand Teachers Council.

Chapman, R. A., Baker, S. B., Nassar- McMillan, S. C., \& Gerler Jr, E. R. (2011). Cybersupervision: Further examination of synchronous and asynchronous modalities in counseling practicum supervision. Counselor Education and Supervision, 50(5), 298-313

Conderman, G., \& Stephens, J. T. (2000). Voices from the field: Reflections from beginning special educators. Teaching Exceptional Children, 33(1), 16-21.

Conderman, G., Morin, J., \& Stephens, J. T. (2005). Special education student teaching practices. Preventing School Failure: Alternative Education for Children and Youth, 49(3), 5-10.

Connelly, V., \& Graham, S. (2009). Student Teaching and Teacher Attrition in Special Education. Teacher Education and Special Education: The Journal of the Teacher Education Division of the Council for Exceptional Children, 32(3), 257-269. https://doi.org/10.1177/0888406409339472

Cresswell, J. (2007). Qualitative Inquiry \& Research Design: Choosing Among Five Approaches. Sage Publications.

Du, Y., Ai, X., Li, Z., Sun, T., Huang, Y., Zeng, X., Chen, X., Rao, F. \& Wang, F. (2021). Visible- to- Ultraviolet Light Conversion: Materials and Applications. Advanced Photonics Research, 2(6), 2000213. https://doi.org/10.1002/adpr.202000213 
Dublin, Ireland

Duncan, D. (2021). Remote Supervision of Group Practice Projects During a Lockdown: A Pedagogical and Experiential Perspective. Journal of Media Education, 12(2), 48-56.

Ergenekon, Y., Ozen, A., \& Batu, E. S. (2008). Evaluation of ideas and suggestions on the teaching practice of teaching mentally handicapped candidates. Educational Sciences: Theory \& Practice, 8(3), 857-891.

Ergul, C., Baydik, B., \& Demir, S. (2013). Opinions of in-service and pre-service special education teachers on the competencies of the undergraduate special education programs. Educational Sciences: Theory \& Practice, 13(1), 518-523.

Feher, L., \& Graziano, K. J. (2016). Online student teaching: From planning to implementation. Online teaching in K-12: Models, methods, and best practices for teachers and administrators, 16(1)109-127.

Flores, M., \& Gago, M. (2020). Teacher education in times of COVID-19 pandemic in Portugal: national, institutional and pedagogical responses. Journal of Education for Teaching, 46(4), 507-516.

Giebelhaus, C. R., \& Bowman, C. L. (2002). Teaching mentors: Is it worth the effort? The Journal of Educational Research, 95(4), 246-254.

Given, L. M. (2008). Purposive sampling. Sage Publications.

Grossman, P., Hammerness, K., \& McDonald, M. (2009). Redefining teaching, re- imagining teacher education. Teachers and Teaching: theory and practice, 15(2), 273-289.

Guilfoyle, K., Hamilton, M. L., \& Pinnegar, S. (1997). Obligations to unseen children. Teaching about teaching: Purpose, passion and pedagogy in teacher education, 183-209. derginin sayis1 yok mu hocam

Harrison, J., \& McKeon, F. (2008, September). The early research career development of beginning teacher educators-a case study approach. In European Educational Research Conference (pp. 10-12).

Hazir, O., \& Kiyak, U. E. (2021). The supervisory practices in a special education department's teaching practice programme: the perspectives of student teachers. Hacettepe University Journal of Education. Advance online publication. https://doi.org.10.16986/HUJE.2021069059

Khan, K. S., Mamun, M. A., Griffiths, M. D., \& Ullah, I. (2020). The mental health impact of the COVID-19 pandemic across different cohorts. International journal of mental health and addiction, 1-7. dergi sayıs1 yok mu?

Kalule, L., \& Bouchamma, Y. (2014). Teacher supervision practices and characteristics of inschool supervisors in Uganda. Educational Assessment, Evaluation and Accountability, 26(1), 51-72.

Kent A. M. \& Giles, R. M. (2016). Dual Certification in General and Special Education : What is the Role of Field Experience in Preservice Teacher Preparation, Professional Educator, 40(2). sayfa no? 
Dublin, Ireland

Klingner, J. K., Ahwee, S., Pilonieta, P., \& Menendez, R. (2003). Barriers and facilitators in scaling up research-based practices. Exceptional Children, 69(4), 411-429.

Leaman, L. H., \& Flanagan, T. M. (2013). Authentic role-playing as situated learning: Reframing teacher education methodology for higher-order thinking. Studying Teacher Education, 9(1), 45-61.

Leko, M. M., Brownell, M. T., Sindelar, P. T., \& Murphy, K.(2012). Promoting special education preservice teacher expertise. Focus on Exceptional Children, 44(7), 1.

Liu W-M, Forbat L, Anderson K (2019) Death of a close friend: Short and long-term impacts on physical, psychological and social well-being. PLoS ONE 14(4): e0214838. https://doi.org/10.1371/journal.pone.0214838

Meegan, S., Dunning, C., Belton, S., \& Woods, C. (2013). Teaching practice: University supervisors' experiences and perceptions of a cooperating physical education teacher education programme. European Physical Education Review, 19(2), 199-214.

Mertens, D. M. (2010). Research and evaluation in education and psychology: Integrating diversity with quantitative, qualitative, and mixed methods. (3rd ed.) Sage.

Morewood, A. (2012). A preservice special education teacher's construction of knowledge : Implications for coursework and retention in the field. American Council an Rural Special Educatian, 31(1), 15-21.

National Council for Accreditation of Teacher Education. (2010, January 5). NCATE Blue ribbon panel initiates a mainstream move to more clinically based preparation of teachers (Press Release). https://files.eric.ed.gov/fulltext/ED512807.pdf

Perry, C. W. (2012). Constructing professional identity in an online graduate clinical training program: Possibilities for online supervision. Journal of systemic Therapies, 31(3), 53-67. https://doi.org/10.1521/jsyt.2012.31.3.53

Rice, M. F., \& Deschaine, M. E. (2020, April). Orienting toward teacher education for online environments for all students. In The Educational Forum , 84(2), 114-125.

Sayeski, K. L., \& Paulsen, K. J. (2012). Student teacher evaluations of cooperating teachers as indices of effective mentoring. Teacher Education Quarterly, 39(2), 117-130

Sergiovanni, T., \& Starratt, R. (2007). Supervision: A redefinition. McGraw-Hill Humanities/Social Sciences/Languages.

Smith, K., \& Lev- Ari, L. (2005). The Place of the practicum in pre- service teacher education: The voice of the students. Asia- Pacific Journal of Teacher Education, 33(3), 289-302.

Stewart, K., \& Williams, M. (2005). Researching online populations: the use of online focus groups for social research. Qualitative Research, 5(4), 395-416.

Tull, M. T., Edmonds, K. A., Scamaldo, K. M., Richmond, J. R., Rose, J. P., \& Gratz, K. L. (2020). Psychological outcomes associated with stay-at-home orders and the perceived impact of COVID-19 on daily life. Psychiatry Research, 289, 113098. 
https://doi.org/10.1016/j.psychres.2020.113098

Dublin, Ireland

Whitaker, S. D. (2000). Mentoring beginning special education teachers and the relationship to attrition. Exceptional children, 66(4), 546-566.

Yucesoy-Ozkan, S., Kaya, F., Gulboy, E., Altun, D. E., \& Oncul, N. (2020). General and Special Education Practices During The Covid-19 Viral Outbreak In Turkey. Educational Practices during the COVID-19 Viral Outbreak: International Perspectives, 19. 